\title{
Gender discrimination In Novel Biru By Fira Basuki
}

\author{
Lisa Permata Sari ${ }^{1}$, Abdurahman $\mathrm{A}^{\mathbf{2}}$, and Yasnur Asri ${ }^{3}$ \\ \{lisapermatasari@student.unp.ac.id ${ }^{1}$, abdurahman.padang@gmail.com ${ }^{2}$, yasnurasri@ fbs.unp.ac.id $\left.{ }^{3}\right\}$ \\ ${ }^{1,2,3}$ Universitas Negeri Padang, Jl. Prof. Dr. Hamka Air Tawar Padang Sumatera Barat 25131, Indonesia
}

\begin{abstract}
This research is motivated by the phenomenon of gender discrimination experienced by women leaders who were targeted male sex object. This novel depicts a strong female figure, brave commanding and so on. However, women are still the object of violence by men. This study aimed to describe gender discrimination in Novel Biru Creation Fira Basukiin the form of marginalization, stereotypes, and violence. The research is a qualitative descriptive method. Sources of data in this study are novel Biru Creation Fira Basukiwhich consists of 340 pages. The results of this study indicate that gender discrimination in the novel Biru 17 data consists of marginalization, stereotypes, and violence. It can be deciphered. First, the form of marginalization of gender discrimination found as many as two data. This is reflected in the characters Gloria are marginalized by their parents so exiled from his family. Second, gender discrimination in the form of stereotypes found as many as eight data. This is illustrated in the figure as the Singapore women SPG (Sarong Party Girl) who likes to hook Caucasians and marry her. Third, gender discrimination violent form found as many as seven data. This is reflected in the characters Gloria getting physical violence on her body that is raped by four men on the way to his house.
\end{abstract}

Keywords: Discrimination, Gender, Women, Novel Biru.

\section{Introduction}

The literary work is not foreign to human life. It can be seen from the resulting works such as poetry, prose, and drama. The literary work is a creation of one's thoughts in the form of the submission of ideas derived from the reality of life. Through literature, one can convey his views on life and appreciate it is written from so that connoisseurs of literature can know the problems that occur in life. an author expressed his views about life in the surrounding[1]. One form of literary works is novel.

The novel as a literary work product, provide various possibilities of human life issues, namely the issue of gender discrimination that distinguishes humans on women and men based on the social and cultural construction[2]. These problems afflict many women's lives are rife from the beginning until now. Many women workers are eliminated and become destitute as a result of the development program. Women are marginalized from the various types of agriculture and industry is more unskilled male and focuses solely on male farmers[3]. Female gender as perceived as being weak and need protection [4]. The differences are constantly giving birth to gender inequality so socialized an imbalance which in general can be detrimental to women [5]. This is the aspect triggers gender discrimination is unfair treatment against one sex between men and women based on cultural construction of the role, functions, political and social life [6,7].

As a written discourse, in the novel, there is one element forming a discourse that genders discrimination.[8]states that gender is a distinction between women and men in the roles, functions, rights, behavior established by the provisions of the local culture. 
Gender discrimination is the denial or restriction made based on gender roles that are socially constructed [9]. Gender discrimination is manifested in various forms, namely (1) the marginalization that the incidence of poverty in society and the state caused by a variety of events, (2) the subordination of the attitude that puts women in a position that is not important and emerging notion that women are emotional or irrational that women could not perform the lead, (3) stereotype (violence) is labeling or tagging adversely group or a certain type, (4) violence that is the attack on the physical and mental integrity psychological, (5) the workload that is processing the household so many women the burden of work more and longer than men [3].

Gender roles can lead to various problems and inequities for women [10]. Depictions of women who are victims of gender discrimination are the depiction of the female figure or a mass-mediated in the literature that tends to marginalize the position of women. In crime news, highlighted many women-related issues of violence, abuse, and sexual harassment. Women are portrayed as objects of exploitation, as a suspect or a victim. There is a presumption that women are invited (fishing) crime on themselves. The depiction of such research is the basis for researching gender discrimination.

The course of a study on gender discrimination last few years has been carried out by various states such as California, Canada, Turkey, Pakistan, India. This can be proved the existence of discrimination and unequal treatment of one gender because of cultural influences, social life, education, politics, and race [11, 12, 13, 14, 15, 16].

Gender discrimination remains a problem in the world are like Europe also occurs gender inequality. This is seen in the finding[17]shows that there has been inequality of women in employment. This is reflected in the level of job satisfaction is lower. In the country of Zimbabwe (city of Gweru) also occur gender discrimination. It can be seen in the findings [18] findings showed in educational institutions are gender discrimination against girls, to reduce gender inequality, Zimbabwe made an international treaty. [19] findings show that discrimination also occurs in primary school students in the 1950 s, 1970 and 1980 in Turkey interviewed with different times since 2010.

Also, based on a review of previous research on gender discrimination has been done before by researchers in Indonesia. Research relevant to this study is [20, 21, 22, 23] The findings indicate that gender discrimination experienced by the female characters, namely marginalization, subordination, stereotyping, violence and workload.

[24] findings show gender discrimination experienced by characters Ginkocaused by gender. This is due to the Meiji era there are boundaries between men and women. [25] Also says in its findings that gender discrimination also occurs in female characters such as physical violence, sexual violence, economic violence, and spiritually caused by poverty, social, psychological, cultural, and weak social control primer that caused this to happen. [26] findings indicate that gender discrimination experienced by Marni figures that Marni had to violate the norms and nature as a woman in the new order era until he reaped the scorn of local communities, [27] findings show that discrimination received by women in the form of subordination and stereotyping in the form of abusive treatment of women caused by the power of the men, causing women is subject to these powers.

When discussed more deeply, women's issues are often present in the literature. It can be seen from the findings earlier. Many women authors who raised and disseminate women's issues such as novelistBiru namely Fira Basuki, raised the issue of gender discrimination. The interesting thing in this novel is the author was able to drag the reader to enter and visualize the position of the character. Therefore, this article discusses the gender discrimination which focuses on the forms of marginalization, stereotyping, violence in the novelBiru creation Fira 
Basuki, Differences of this study is contained in the object and the depiction in analyzing the object. This study aimed to describe, analyze and interpret the detailed and systematic form of gender discrimination against the novelBiru creation Fira Basuki.

\section{Method}

This study used a qualitative descriptive study [28] With the objective of gender discrimination in the novel describes Biru creation Fira Basuki, This research data in the form of words, sentences, paragraphs contained in the novelBiru creation Fira Basuki, Sources of data in this study is novelBiru creation Fira Basuki published PT Grasindo 2003 consists of 340 pages.

The data collection technique is technical documentation. Steps, namely (1) read and understand novelBiru creation Fira Basukias a whole to get a thorough understanding, (2) identify the data, (3) classifying the data, (4) recording the data has been classified. The data analysis technique used is the technique description. The steps do is (1) to read the classified data, (2) analyzing the data, (3) summed up the results of the analysis.

\section{Results and Discussion}

History penalties describe gender discrimination that consists of marginalization, subordination, stereotyping, violence, and double burden. But after reading and analyzing the novelBiru Fira Basuki's work. The data in this study focused on marginalization, stereotypes, and violence against gender discrimination in the novelBiru creation Fira Basuki.In this novel Fira Basuki try dragging the reader to be able to sign and imagine if it was in the position of each of the characters. The results of this study indicate that gender discrimination in the novel Birucreation Fira Basuk 17 data consists of marginalization by 2 data, the stereotype as much as 8 data, and violence as much as 7 data.

\section{Marginalization}

Marginalization is a process of marginalization in the field of work that resulted in poverty to one gender. For example, evictions, natural disaster or the exploitation process, food selfsufficiency program or the green revolution (green revolution) economically have removed the woman from his job so that impoverish them. The marginalization can be seen from the excerpt below:

This event draws on Aris concern of street children living in slums, of suburban railroads Pejempongan, under bridges Layang Klender, until the edge of the area Tanah Abang times. They live in poverty, poor as a beggar. This is evidenced by the following quote.

(1) "Ini sarang anak-anak tak punya, mereka hidup sebagai pengemis cilik, dagang asongan, dan mungutin sampah...melarat, " begitu katanya, yang dimaksud tentu saja anak-anak yang tinggal dipinggir kali dan di bawah jembatan di Jakarta".

The quote above indicates that street children and children living in the outskirts times get gender discrimination in the form of marginalization. This is evidenced by the quote " Ini sarang anak-anak tak punya, mereka hidup sebagai pengemis cilik, dagang asongan dan mungutin sampah" these quotations indicate that the children periphery marginalized with a life of poverty, they have to work hard to survive, although it must be a beggar.

These events illustrate the character Gloria who raped until pregnant. These events resulted in Gloria expelled by his parents because of shame and no longer recognizes as his daughter Gloria, Gloria was forced to leave home because their parents no longer want her, despite the 
disaster suffered by Gloria is not merely of his behavior. But Gloria did not dare to tell her what happened to her. This can be seen in the quote below.

(2) "Kamu terpaksa keluar dari rumah besar itu Gloria. Papi memutuskan untuk pindah kembali ke Manado, dengan mami dan kakak-kakakmu..tapi..kamu tidak diajaknya. Kami akan membiayai anak itu, Gloria. karena kami umat beragama, tidak percaya pembunuhan sebuah janin yang diciptaknnya dan membawa pesan. Cuman ayahmu keras Gloria".

In the quote above indicates gender discrimination-shaped Gloria get marginalization. This is evidenced by the quote "Kamu terpaksa ke luar rumah Gloria, Papi memutuskan untuk kembali pindah kemanado dengan mami, kakakmu, tetapi kamu tidak di ajak" the statement signifies Gloria marginalized from the release because the parents Gloria embarrassed by the state of Gloria that now, because before Gloria was the only child to be proud of his family. But that changed when Gloria made a disgrace to his family.

\section{Stereotype}

The stereotype is labeling or tagging against gender-restricting effects or harm one sex get unfair treatment. For example, marking the beginning of sums that women preening is to lure the attention of the opposite sex. Stereotypes can be seen in the excerpt below.

His incident tells the story of Su lin telling his homecoming named Roger who brought another girl who was not his wife, but the young and passionate woman. This can be seen in the quote below.

(3) "Dua puluh tahun, bayangkan! Muda dan bergairah. Yang jelas si perempuan itu sungguh SPG (Sarung Party Girl), Julukan untuk perempuan Singapura yang memang niat menggaet bule dan kalau bisa menikahinya".

In the quote above indicates young women (female Singapore) get a form of gender discrimination stereotypes. This can be evidenced by the quote " yang jelas si perempuan itu sungguh SPG (Sarung Party Girl)". Said SPG (Sarong Party Girl) is negative labeling obtained by women in Singapore. Labeling Singapore arises because women often rake in Caucasians and marry her.

This event tells the story of Mita conducting illicit relations (sexual relations) with one of a man who was a friend of his parents. This prohibited relationship occurs because Mita likes her security, Mita did not realize until the act of doing will ruin himself. In the end Mita apologetic and admitted his guilt to his parents. This can be seen in the quote below.

(4) "Kemudian pak Aris itu Ma, yang tadinya si Gepetto, memberi napas seperti Peri Biru. Si peri Biru yang baik. Tapi Mita tidak sadar ketika ia berubah wujud jadi si Stromboli, memiliki Mita".

In the quote above indicates Aris obtain shaped stereotypical gender discrimination. This can be evidenced by the quote " Ia berubah wujud jadi si stromboli". This labeling occurs because Mita imagines Aris like Stromboli, which has the attitude and expertise in seducing women and Hafa satisfies his lust. So the woman who approached him was trapped with his seduction persuasion.

This event tells the story of the meeting of parents Mita laments about life suffered. This happens, for Mita imagine a beautiful life. But in the end all is not as expected Mita. Mita disappointed with the actions to overwrite the bad luck, and blamed by his friends who are proud of the events that happened. This can be seen in the quote below.

(5) "Ternayata tidak Ma. Teman Mita, Desi juga, Normala juga, Becky, dan mungkin banyak lagi. Ini gara-gara Desi justru bangga dan mengaku pada kita-kita. Mita langsung seperti roboh, langsung rasanya sakit luar dalam. tapi mengapa Desi 
bangga, Ma? Ketika perempuan-perempuan lain itu berubah menjadi keledai, berjalan, bersuara dan berlagak aneh...mengapa Mita yang seperti Pinokio, baru bertelinga dan berekor keledai, tapi belum berubah wujud, ketakutan? Mita mencoba berlari dari pulau miliknya".

In the quote above indicates, Mita friends get gender discrimination in the form of stereotypes (negative labeling) of Mita. This is evidenced by the quote " perempuanperempuan lain itu berubah menjadi keledai, berjalan, bersuara dan belagak". The mention of this donkey appeared as Mita very disappointed with his friends who had made him fall kelembah destruction. Mita equates her with Donkey.

These events tell about the pain suffered by Mita. Mita took a big hit on the events that happened. The downturn caused Mita can not hold it and told her parents. This can be seen in the quote below.

(6) "Lebih sakit lagi ternyata, Mita memang boneka mainannya, pinokio yang tadinya gembira dihidupkannya, dimainkannya untuk pertunjukkan dan diajak senangsenang hingga jadi keledai. Dia tertawa puas Ma, sementara Mita sebelum ini serasa Pinokio berhidung panjang, berbohong terus, menyimpan ini dari mama".

In the above quotation indicates gender discrimination Mita give to him in the form of negative labeling (stereotypes). This labeling appears as Mita blames himself that gullible, deceived by the persuasion of others. Mita admitted his guilt to his parents until Mita felt like long-nosed Pinocchio who had lied to their parents.

These events tell about the disappointment of parents Mita to Aris who is his own. This can be seen in the quote below.

(7) " Ibu mana yang tidak terenyuh mendengar putrinya berbicara demikian. Hatiku terasa disayat-sayat tipis hingga kesumsum tulang. Aris brengsek! Biadab! Binatang ".

In the above quote, Aris gets gender discrimination from Mita's parents in the form of stereotypes (negative labeling). This can be evidenced in a quote " Aris brengsek! biadab! binatang". This labeling arises because of parents Mita very disappointed with Aris's treatment to their children. Aris has damaged personality Mita's cause was devastated and always blames himself for the events that happened. Parents Mita did not receive treatment to his son until his Aris could not contain his anger and harsh words came out of his parents.

This event tells the anger of parents Mita to Aris who has left wounds to his son, but Mario is a friend Aris defended and communicating Aris kindness to others. But Mita's parents ignore the slightest kindness of Aris. This can be seen in the quote below.

(8) "Aku tidak peduli lagi jika ia membantu banyak orang, atau bahkan si Ondi, anak jembatan yang bau dan kumal dulu. Yang kupeduli sekarang adalah nasib Mita. Nasib buah hatiku sendiri ".

In the quote above indicates a bridge child get gender discrimination by parents Mita shaped stereotypes (negative labeling). This is evidenced by the quote " Anak jembatan yang bau dan kumal dulu". This labeling occurs because of resentment and disappointment parents when Aris Aris Mita to help children bridge with him.

This event tells of disappointment Rahman (parents Mita) to his daughter Mita who does not want attention from his father. Although father Mita very ignored and anxious about the state of Mita. This can be seen in the excerpt below.

(9) "Aku dianggapnya monster, Ma, "keluh bang Rahman. Aku mencium pipi suamiku itu. Sabar, Pa.’Hebat sekali pria itu Ma, ia merusak keluarga kita, "katanya lirih". 
In the above quote Bang Rahman obtain gender discrimination by Mita (daughter) in the form of stereotypes (negative labeling). This is evidenced by the quote " Aku dianggapnya monster". Said the monster is a form of negative labeling received by Bang Rahman. This labeling happened because Mita considered all the man's attitudes to be the same as his own. Mita traumatized by the events that happened until he identifies his father with others.

This event tells about the origin of Aris who does not know who the father is. Aris always finds out the identity of her to any person who is close to his mother, but Aris never knowing who his real father. This makes Aris upset and blames himself. can be seen in the excerpt below.

(10) "Ini mungkin menjawab pertanyaan, siapa aku? aku berasal dari darah kotor dengan napsu binatang. Darah seorang pria pemerkosa yang mengalir kenadinadiku. Aku terlahir demikian! Aku terlahir dari seorang suci perawan, ibuku yang bernama Gloria".

In the quote above indicates Aris obtain gender discrimination against him that is shaped stereotypes. Negative labeling is obtained Aris Aris considers itself derived from animal lust.

\section{Violence}

Violence is an attack or invasion (assault) against the physical and mental integrity of a person's psychology. Gender violence caused by power inequalities that exist in society. The violence can be seen in the following excerpt.

This event tells the story of Mama Greta's anger at Horison who has dropped food (chicken porridge) to the plate and the food scattered about. Mama Greta angry because the funds to replace the plate will be taken from the fund orphanages, but the fund is not to replace other damages like broken dishes chicken porridge. Anger Mama Greta inflicts pain by Horison is a punishment that is not reasonable. This can be seen in the quote below.

(11) "Aku tidak bisa memaafkanmu, sejak pertama kali! Tidak bisa!’Mama Greta menggeret tanganku dengan paksa dari kursi. Aku diseret-seret hingga kedua sepatuku yang menggeser lantai berdenyit-denyit".

The quote above indicates Horison gets the violent form of gender discrimination by Mama Greta. Horizon obtained violence can be seen in the quote " Mama Greta menggeret tanganku dengan paksa dari kursi, Aku diseret-seret hingga kedua sepatuku yang menggeser lantai berdenyit-denyit". The word being dragged is obtained Horison violence. This violence occurs because Mama Greta does not accept behavior that has been dropped food Horison until strewn.

This event tells the story of disappointment, anger Mama Greta at Horison who had ruined his life. Greta mama loved lover left him because Horison that suddenly appeared in the room, Mama Greta. Until Mama Greta's anger peaked for Horison Dropping food until scattered. These events cause mama Greta revenge on the Horizon. Although the Horizon does not know the least of the event experienced by Mama Greta. This can be seen in the quote below.

(12) "Aku tidak mengerti apa yang diucapkannya. Tapi Mama greta mengancamku dengan tatapan pisaunya yang siap mengiris-ngiris tubuhku. Aku pun berhenti berteriak. Percuma. kerongkonganku kering dan telinganya seakan tuli. Meronta juga tiada arti. Jadi akau seperti anak anjing, menurut saja. Dirantai tangan dan kaki, kepala ditekan dan ditundukkan".

The quote above indicates Horison gets the violent form of gender discrimination by Mama Greta. Violence obtained Horison form of mental abuse and physical violence in the form of a threat then Horison he chains hands and feet. This violence occurs because of 
disappointment Mama Greta told Horizon that has ruined his life. coupled with the food being dropped by Horizon to place food dishes broken and strewn on the floor. This incident adds to the anger Mama Greta against Horison.

These events tell about the abuse sexual conducted by Rick to Cindy. This happens when they're looking at a show. Mid-Events Rick performs the unnatural treatment to Cindy. This can be seen in the quote below.

(13) "Duh...apa lagi nih? Rick...not again, please," pintaku. Tangannya kini merogoh-rogoh rok bawahku yang mini. Jarinya mulai memainkan celana dalamku".

In the quote above indicates, Cindy obtains gender discrimination in the form of physical violence by Rick. This can be seen in the quote " tangannya kini merogoh-rogoh rok bawahku yang mini dan memainkan celana dalamku". Words fumbled and play my underwear is a form of physical abuse received by Cindy. This violence occurs because Rick wanted to vent their lusts to Cindy.

This event tells the story of Cindy's career while in Singapore with Robin. In Singapore, Cindy taught how to walk on the catwalk, how to smile and pose, to manners and social ethics. But one night Robin brazen act to Cindy. This can be seen in the quote below.

(14) "Tapi suatu malam, bibir Robin menyentuh bibirku. Tubuh yang besar itu menindihku di sofa. Tiba-tiba ia menjadi sangat laki-laki. Dengan kasar ia melepas kaosnya. Kemudian tanpa izinku ia melumat bibirku hingga hidungnya menggenjet rata hidungku. Aku tidak bisa bernafas dan tidak bisa berontak. Begitu lemas berada di bawahnya. aku merintih halus. Sakit. Bagian bawahku sakit. "Robin..ah..ja..ja..jangan..”. Ia tidak memberiku kesempatan. Semuanya terjadi. Vaginaku robek, sofa terkena noda darahku. Aku menangis tersedusedu".

In the above quote, Cindy obtains gender discrimination in the form of physical attacks by Robin. Cindy obtained violence contained in the said crushing, touched my lips, crushed my lips, pussy torn. The violence began when Robin was unconscious in his sleep. Robin with raping Cindy rough sleeping. However it is felt by Cindy to Cindy struggled, but Robin ignored rebellion, Cindy.

This event tells of disappointment Lindih to her husband cheating with her classmates. The incident began when Lindih see Setiawan (her husband) were in the same car with his friend. Lindih then follows the car. Unexpected turns in the car are the husband Lindih. To be sure, the next tomorrow Lindih returned to the house. Lindih anger peaked when I saw they were in the same room. This can be seen in the quote.

(15) "Lindih menendang pak Gamut yang mencoba mendekat, ia bahkan menggigit lengan Yu Iyah yang menahannya. Dibukakanya pintu kamar tadi yang tidak terkunci".

In the quote above the father, Gamut get gender discrimination in the form of physical violence by Lindih. This violence is contained in the word kicking, biting. This violence occurs because the pack approached Lindih Gamut to try to reclaim the dagger held Lindih. However Lindih plays with me for holding the machete, so it was forced to pack Gamut Lindih kick that was holding a machete stay with him.

This event tells the story of the feud between Lindih, Kira and Setiawan. Guess who did not receive treatment Lindih guess tells him that he has officially become the wife Setiawan. However, Lindih still did not accept what was said by Kira and her husband told her of betrayal that is having an affair with his friend. Lindih did so desperate to kill Setiawan. This can be seen in the quote below. 
(16) " Buktinya bisa. Kami menikah resmi...seminggu lalu...’Lindih melotot dan kian menekankan ujung golok yang membuat leher Setiawan sedikit berdarah".

In the above quote, Setiawan gets gender discrimination in the form of physical violence by Lindih. Violence is in getting there in the sentence Setiawan pressed the dagger that made the Setiawan bloody neck. This violence occurs because Lindih felt betrayed by her husband and herself. Until the feud between Lindih with Kira. Without thinking long Lindih pressed the dagger into the neck Setiawan.

This event tells the story of Gloria's fear when entering a narrow alley toward his home, on the way Gloria collided with four men were grim, rough who want to harm Gloria. This can be seen in the quote below.

(17) "Belum sempat teriak, mulutnya dibungkan dengan kain lusuh. Demikian pula matanya pun ditutup. Meronta tiada guna, seperti ayam yang hendak disembelih. Akhirnya Gloria hanya pasrah sambil terus membaca doa. Baju seragamnya dicabik-cabik hingga punggung Gloria merasakan dinginnya lantai, entah lantai rumah siapa. Dengan pandangan gelap, tangan dan kaki diikat, Gloria Cuma bisa merasa. Tubuhnya dijilati dan digigit sana-sini beramai-ramai sekan-akan ia adalah ayam pagang. Dua buah dada kebanggaanya tak lupa dibagi untuk empat orang. Yang kemudian tidak mau melewatkan melahap bagian terenak yang suka dilarang-larang, yaitu simbol kewanitaan yang mungkin mereka anggap bak brutu ayam".

In the above quotation Gloria obtain gender discrimination in the form of physical abuse of four men were grim and rude. Violence obtained by Gloria illustrated by the quote "Mulutnya dibungkam dengan kain lusuh, baju seragamnya dicabik-cabik, tangan dan kaki diikat, Tubuhnya dijilati dan digigit sana-sini beramai-ramai, dua buah dada kebanggannya dibagibagi untuk empat orang, melahap bagian terenak yaitu simbol kewanitaan ". The quote is a form of violence experienced by Gloria. This event occurs because Gloria walking in a deserted place and was followed by some evil men.

\section{Discussion}

This section will discuss some of the findings related to the aspects that have been analyzed. After analyzing the gender discrimination that consists of marginalization, stereotyping, and violence in the novelBiru creation Fira Basuki, In theory, invented [3] (there are five forms of gender discrimination. However, the researchers limit by analyzing the third part of gender discrimination by the novel being investigated.

In the novel Birucreation Fira Basuki there is gender discrimination against women named Gloria, Gloriasuffers injustice since he was unfortunate when school is gang-raped by a bunch of lads. The tripGloriaconfronted by a swarm of men inhuman until this tragedy happened. Injustice occurs in various forms such as marginal or economic impoverishment process, stereotypes or negative labeling, physical and psychological violence. As a result of gender inequalities experienced byGloria cause Gloria expelled from the house and abandoned by their families.

\section{Conclusion}

Based on the findings that have been made, it can be concluded that gender discrimination 17 data consists of marginalization, stereotypes, and violence. It can be described as following. First, the form of marginalization of gender discrimination found as many as 2 data. 
This is illustrated in figureGloriaare marginalized by their parents are estranged from the family. Second, the form of stereotyping gender discrimination found as many as 8 data. This is illustrated in figureMitawhich gives a negative label to him that long-nosed Pinocchio. Then stereotype also be obtained by women Singapore as SPG (Sarong Party Girl) who likes to hook Caucasians and marry her. Third, gender discrimination in the form of violence was found as much as 7 data. This is illustrated in figure This is reflected in characters Gloria getting physical violence on her body that is raped by four men on the way to his house.

\section{Acknowledgements}

The author would like to thank the lecturers who have provided input and assistance for completing this article.

\section{References}

[1] Rokhmansyah, A.: Studi dan pengkajian sastra. Yogyakarta: Graha Ilmu. ( 2014)

[2] Atmazaki.: Ilmu sastra: Teori dan terapan. padang: UNP Press. (2007).

[3] Fakih, M.: Analisis gender dan ransformasi sosial. Yogyakarta: Pustaka pelajar, (2013)

[4] Siregar, M.:Ketidaksetaraan gender dalam Dalihan na Tolu. vol. 3, pp. 13-15. A Jurnal Studi Kultural (2018)

[5] Sultan, H. L.:Konsepsi Hukum Islamterhadap Kesetaraan Gender (Studi tentang Peran Politik Wanita Muslimah). vol. 8, pp. 73-87. Jurnal Al-Adi (2015)

[6] Muqoyyidin, A.: Wacana kesetaraan gender: Pemikiran islam kontemporer tentang gerakan feminisme Islam. vol. 13, pp. 490-511. Jurnal Al-Ulum. (2013)

[7] Rokhimah, R.: Patriarkhisme Dan Ketidakadilan Gender. vol. 6, pp. 132-145. Jurnal Muwazah(2014)

[8] Nugroho, R.:Gender dan strategi pengarus - Utamanya Di Indonesia. Yogyakarta: Pustaka Pelajar, (2008).

[9] Folami, F. F.: Gender inequality and role-strained among male nursing students in selected nursing institution, Lagos, Nigeria.vol. 5, pp. 214. Journal of Education and Training Studies (2017)

[10] Suhra, S.: Kesetaraan gender dalam perspektif Al-Qur'an dan implikasinya terhadap hukum Islam. vol. 13, pp. 373-394. Jurnal. Al-Ulum. (2013)

[11] Phillips, A. L. andPhillips, G. M.:The persistence of traditional gender stereotypes: evidence from the distribution of academic honors at A female-Majority University. vol. 3, pp. 45-54. American Journal of Business Education (AJBE) (2010)

[12] Mackenzie, S., Talbott, A.: Gender justice/gender through the eyes of children: A photovoice project with elementary school gender expansive and LGBTQ-parented children and their allies. vol. 18, pp. 65. Sex Education: Sexuality. Society and Learning (2018)

[13] Kahn, M andGorski, P. C.:The gendered and heterosexist evolution of the teacher exemplar in the united states: Equity implications for LGBTQ and gender nonconforming teachers. vol. 18, pp. 15-38. Journal. Multicultural. Education(2016)

[14] Kalaychi, N and Hayirsever, F.: An analysis of citizenship and education text book in the context of gender equality and determining students' perceptions on gender equality. vol. 14, pp. 1065-1074. Educational. Sciences. Theory Practice (2014)

[15] Shaukat, S., Siddiquah, A., and William Pell, A.: Gender discrimination in higher 
education in Pakistan: A survey of university faculty. vol. 14, pp. 109-126, Egit. Arastirmalari - Eurasian Journal of Educational. Research (2014)

[16] Misra, S. N andGhadai, S. K.: Feminism, budgeting and gender Justice. vol. 8, pp. 149-154. Journal. Education. Practice(2017)

[17] Perugini, C and Vladisavljević, M.: Gender inequality and the gender-job satisfaction paradox in Europe. vol. 60, pp. 129-147. Labour Economics (2019)

[18] Matope, N.: Gender discrimination in educational personnel: A case study of gweru Urban district secondary Schools, Zimbabwe. vol. 7, pp. 689-696. Online Submiss (2012)

[19] Saglam, M andSungu, H.: Teachers' discriminations in the narratives of primary school students of different periods in Turkey: 1950s, 1970s and 1980s. vol. 3, pp. 793-799. Universal. Journal Educational Research (2015)

[20] Hayati, Y.: Representasi ketidakadilan gender dalam cerita dari Blora karya Pramoedya Ananta Toer: Kajian feminisme. vol. 15, pp. 163. Atavisme (2012)

[21] Astuti, S.: Ketidakadilan gender dalam novel Namaku Mata Hari karya Remy Sylado: Kajian Feminisme.pp. 487-495. Jurnal Pendidikan bahasa dan sastra Indonesia(2012).

[22] Liasna, T and Ansari,K.: Gender perspective the novels Padang Bulan and Cinta di dalam Gelas by Andre Hirata. vol. xv, pp. 207-215. Jurnal Humanus(2016)

[23] Astuti, P. \& Gede, w.: Ketidakadilan gender terhadap tokoh perempuan dalam novel genduk karya Sundari Mardjuki: kajian kritik sastra feminisme. vol. 2, pp. 105-114. Jurnal Ilmu Budaya (2018)

[24] Unsriana, L.: Diskriminasi gender dalam novel Ginko Karya Junichi Watanabe. vol. 8, pp. 40. Lingua. Cultura (2014).

[25] Prasetyo, Y.: Kekerasan terhadap tokoh perempuan dalam novel Seperti Dendam Rindu Harus Dibayar Tuntas dan Lelaki Harimau Karya Eka Kurniawan. vol. 6, pp. 152-160. Seloka Jurnal Pendidikan Bahasa dan Sastra Indonesia (2017)

[26] Setyorini, R.: Diskriminasi gender dalam Novel Entrok Karya Okky Madasari: Kajian Feminisme. vol. 4, pp. 291. Jurnal. Desain (2017)

[27] Susanti, S.: Analisis ketidakadilan gender pada tokoh perempuan dalam novel Kupukupu malam karya Achmad Munif. vol. 10, pp. 713-723. Jurnal. Artikulasi, (2018)

[28] Moleong, L. J.: Metodologi penelitian kualitatif. Bandung: Remaja Rosdakarya, (2010). 